\title{
APPRAISING THE LEVEL OF YOUTHS' INVOLVEMENT IN SELF-HELP COMMUNITY DEVELOPMENT PROJECT IN SOKOTO NORTH LOCAL GOVERNMENT AREA, SOKOTO STATE
}

\author{
GAMBO, NURA DUTSIN-MA \\ Dept. of Adult Education \& Extension Services, Usmanu Danfodiyo University, Sokoto, Nigeria \\ HARUNA, MARYAM ILLO \\ Dept. of Educational Foundations, Usmanu Danfodiyo University, Sokoto, Nigeria
}

\begin{abstract}
Self help Community Development projects are basic requirements by any settlement for its effective and proper functioning and vital for the overall development of the community. This paper intends to appraise the level of youth involvement in self-help community Development Projects in Sokoto North local Government area and the problems militating against the performance of youths' involvement in self-help community development projects. The research uses survey method of data collection which has been conducted in the Sokoto North local Government Area. A sample of 100 youths 'was used using Simple random sampling method. The following research questions guided the study: What are the self-help communities Development Projects undertaken by the youth in Sokoto North local government area? What are the areas of youth involvement in Self-help Community development projects in Sokoto North Local government area? And what are the problems against the performance of youth's involvement in Self-help community development projects in Sokoto North local government area? An instrument used for this study was structure questionnaire which was validated by experts from the faculty of education and extension services, department of Adult education and extension services Usmanu Danfodiyo University Sokoto. For it consistency I have pilot tested Sokoto South local Government area. The research used descriptive method of data analysis in form of percentage. The research finds out that the youth in Sokoto North local Government area undertakes six major self-help community development projects which are construction of drainage, culvert excavation, construction of mosque, and construction of slop among others. The research also finds out that the problem associated with community development efforts in the area are financial constraints, lack of educational enlightment, and lack of cooperation and mismanagement of project fund among others. The research recommends that there should be improve funding and support from government and related agencies in order to enhance activities of youth's in Self-help Community Development Projects in the area. Also there should be educational enlightenment for youth to participate in the selfhelp community Development Projects. Finally youth's should be made to understand the benefit of Self-help Community Development Projects.
\end{abstract}

\section{Introduction}

From the earliest period of human history people have enjoyed and shared together the good tidings of nature because of the existence of communities and the social activities engaged by the people for the progress of their community, which is better called Community Development. Community development marks the stage in the life of a community where by members come together to take collective actions in order to generate solutions to their identified problems. Community development in this context can be said to be a self-directional effort of the people by the people and for the people. For Hill (2011), it means a coordinated approach whereby the community members undertake programs and projects in order to better the living condition of the people residing in that community. This according to Johnson (2008) implies the improvement in the physcal and material wellbeing including livelihood of people in the community. Community development therefore, help people to recognize and develop their ability and potential in order to address their problems and needs which they share (Effiong, 2012). 
In Nigeria, self-help community development is not new. Oduaran (1994), Tolu and Abe (2011) observed that before the advent of colonial administration, various communities designed development-oriented activities on their own in order to improve their standard of living such as vigilantes to provide security in the community, drainages clearance and construction of local market. The spirit of self help which forms the present day strategy for community development guided the zeal of the people as they harnessed their local resources and undertook community development projects like building of Islamiyya schools, vigilantes, rural, road expansion and maintenance, drainages clearance, sanitation, tree planting to check erosion amongst others. Hence, self-help community development could be regarded as a skilled process which hinges on the approach that controls and uses assets to promote social justice and improves the quality of community life.

From the foregoing, self-help community development projects in Nigeria are basically an attempt to address the "felt needs" of the masses by the people and for themselves. According to Oduaran (1994), self-help community projects are those tangible ventures that the inhabitants of the community embark on, in order to improve the conditions of people residing in that community. One of the basic assumptions of self-help community development project, is that community development activities are all inclusive as it provides opportunity for people to learn and grow thus, ensuring that no segment of the populace is exempted, youths inclusive. The youths in question can be conceptualized as a people within the age bracket of 13 and 24 years (Live right, 2013), 15 and 24 (UNESCO, 2015), but varies around the world (UN, 2008). For example in Nigeria youths are limited to the ages between 16 and 35 years, whereas in Cameroun it is a period between the age of 14 and 25 (World youth data sheet, 2010). Youth is a period of transition from being dependent to construction of self concept, being influenced by peers, life style and gender. Youths constitute the most active labor force of every community. There are about 1.2 billion youths between the age bracket of 15 and 24 years old in the world and about one billion live in developing countries (World Bank Report, 2010). Similarly, National Bureau Statistics Youth Survey Report (2012) showed that nearly $50 \%$ of developing world population are youths within the age bracket of 15 and 35 . This is often referred to as the youth bulge, since young people constitute a high proportion of many country's population as evidenced in Nigeria with a population over 174,507,539 million people out of which 64 million are youths with about 54\% of them unemployed (Nigeria National Baseline Youth Survey, 2015).

Hence, the need for this study which seeks to appraise the level of youth's involvement in self-help Community Development Projects. Any attempt to examine their involvement must require the gathering of information using various methods to systematically assess the effectiveness and efficiency of the subject being investigated. Assessment according to Maxwell (2013) is the coordinated process of evaluating, investigating and examining a given phenomenon in order to ascertain useful information and feedback that will be used to address pertinent problems about the phenomenon. Thus, this study will provide information on the self-help community development projects embarked upon by communities in the study areas, ascertain the areas of youth's involvement and the impact of youth's in self-help community development projects and finally finds out the constraints to youths 
involvement in self-help community development projects in Sokoto North Local Government Area of Sokoto State.

\section{Statement of the Problem}

Most communities in developing countries like Nigeria are known for embarking on self-help development projects but to complete the projects is a problem. Consequently, it appears that their efforts are not commensurate with all they have invested. It seems not possible to even ascertain the areas and level of involvement of all stakeholders in the communities especially the youths who are supposed to fast track development activities in their communities. Although, literature showed that community development officers and experts especially in developing countries, like Nigeria, have frowned at the low involvement of youths in community development. So many reasons have been adduced for such anomaly, which includes; that youths seem not to be considered as matured people and as such have been excluded right from decision making process, planning, implementation, supervision and evaluation of community development projects by community Development stakeholders.

Therefore, the researcher intends to appraise the level of youths' involvement in selfhelp community development projects in Sokoto North Local Government Area of Sokoto State.

\section{The Study Area}

Sokoto North Local Government dated back to the establishment of the ancient city of Sakkwato, as the then administrative capital of the Sokoto caliphate, in 1809 by sultan "Muhammadu Bello". Sokoto Local Government was also created by General Murtala administration in the year 1976, as one of the pioneer Local Government in the federation. It than comprises of Kware and Wamakko Local Governments which were later created out of the Sokoto Local Government. After the creation of Sokoto South from what remain of Sokoto Local Government in 1996 by the Abacha administration, it was renamed to what is known as Sokoto North Local Government.

Sokoto North Local Government Area has a landmass of 31SQKM and a Population of 232,846 people. There are Hausa Fulani, the other Nigerian tribes. There is foreign national residing in the eleven words (11) of the area. Islam is the major religion, with Hausa Language as the predominant language. Trading, farming, labour services and crafts are the main occupations; the area is geographically located at the centre of Sokoto State mapping. It share border with Kware Local Government (North east) South Sokoto (South) and Wamakko (west). Major among the historical monuments in the area includes: Sultan palace, Hubbaren Shehu (Shehu Tomb) Usman Danfodiyo and Sultan Bello mosques among others.

\section{Review of Related Literature}

Many researchers are available that have been carried out on the impact of youth's involvement in self help community Development Project for instance Nwankwo, Anderson and Ezenyem (2008) carried out a study titled "Factors Militating against the Involvement of Women in Community Development Projects in Oyi Local Government Area of Anambra State". The population for the study consisted of 550 registered members of women organizations in the local government. The researcher 
used simple random sampling technique to determine the sample size of 300 respondents for the study. A 20 -item questionnaire was the instrument used to elicit information from the respondents. The data were analyzed using mean and standard deviation. The findings revealed that illiteracy among majority of the women and inadequate mobilization were major factors that affected the women's involvement in community development projects in Oyi Local Government Area of Anambra state. The study is related to this present study because both studies focused on involvement of youths and women in community development projects but differed from the former which examined only the factors militating against the involvement of women in community development projects while the present study was centered on ascertaining the projects embarked upon, areas impact of youths involvement in self help community development projects and the constraints.

Anderson (2005) carried out a study to determine the level of youth's participation in community development projects in Lima town in the South American country of Peru. The study adopted a descriptive survey research design. The population for the study was 150 youths purposively selected from 305 youths in five localities. There was no sampling because the population was a manageable size. Using a one way analysis of variance (ANOVA) to analyze the data, it was revealed that a small percentage of $31.5 \%$ or 71 youths involved voluntarily in community development projects in Lima, while majority $68.7 \%$ of youths, because of their illiteracy and poverty, exhibited a laissez faire attitude towards the development of their community. Both studies are related in scope but differed in the analytical tool used and the area of study.

Finally, Ezenyem (2012) carried out a study titled "Families Involvement in Self-help Community Projects for Sustainable Development: A Case Study of Amadunu Community in Nnobi Idemili South Local Government Area of Anambra State". The population of the study consisted of 250 respondents. Questionnaire was used for data collection, while simple percentage was used to analyze the data collected. Some of the major findings were that: the people of Amadunu community participated actively in community development efforts as could be seen from the various projects they embarked upon and which some were completed, while others were nearing completion. Ezenyem's study is related to this present study because both emphasized on self-help community development but vary in the aspect that the former centered on families involvement in self-help projects while the later focused on youths involvement in self-help community development projects.

\section{Objectives}

The objectives of this study are:

1. To find out self help community development projects undertaken by the youth's in Sokoto North's Local Government Area

2. To find out the areas of youth's involvement in self help community development project in Sokoto North Local government Area

3. To find out the impacts of youth's involvement in self help community development project in Sokoto North Local Government Area. 
4. To identify the problems against the performance to Youth's involvement in self help community development projects in Sokoto North Local Government area.

\section{Research Questions}

This study was guided by the following research questions

1. What are the self-help community developments projects undertaken by the youth in Sokoto North Local Government Area?

2. What are the areas of youth's involvement in self-help community development project in Sokoto North Local Government Area?

3. What are the impacts of youth's involvement in self-help community development project in Sokoto North Local Government Area?

4. What are the problems militating against the performance of youth's involvement in self-help community development project?

\section{Research Methodology}

This study employed survey method of data collection. The sample of 100 youth in Sokoto North Local Government Area is used. Structured questionnaire is designed and used in order to collect data for this study. The data was analyzed using simple and percentage frequencies.

Data Analysis and Discussions

This section is concern with the presentation of data, analysis and interpretation of the results. Descriptive statistics is presented and discussed.

\section{Descriptive statistics}

Table 1: The percentage of distribution of respondents according to socioeconomic characteristics

\begin{tabular}{lll}
\hline Socio-economic characteristics & Frequency & Perce \\
\hline Age & & \\
& & \\
15-19 years & 8.00 & 13.30 \\
20-24 years & 25.00 & 41.70 \\
25-29 years & 19.00 & 31.70 \\
30-34 years & 8.00 & 13.30
\end{tabular}

Sex

Male

$36.00 \quad 60.00$

Female

$24.00 \quad 40.00$

Academic qualification

Secondary school attended

$8.00 \quad 13.30$

Secondary school completed $\quad 24.00 \quad 40.00$

OND/NCE

15.00

25.00 


\begin{tabular}{lcc} 
& & North Local Government Area, Sokot \\
\hline HND & 8.00 & 13.30 \\
Higher degree & 5.00 & 8.30 \\
Primary occupation & & \\
Student & 54.00 & 90.00 \\
Civil servant & 6.00 & 10.00 \\
Secondary occupation & & \\
Rice farming & 40.00 & 60.00 \\
\hline
\end{tabular}

Table 1 above represents percentage of distribution of respondents according to socioeconomic characteristics

What are the Self help Community Development Project embarked on by the youth's in the Communities in Sokoto North LGA:

Table 2: Projects embarked on by the youth's self-help community development projects in the area are sanitation, constructions of culvert, drainage, mosque, borehole, slop, town hall and tree planting

\begin{tabular}{lccc}
\hline Item Strongly Agree & Agree & Strongly Disagree & Disagree \\
\hline Construction of Drainage40\% & $60 \%$ & $0 \%$ & $0 \%$ \\
Culvert Excavation $50 \%$ & $50 \%$ & $0 \%$ & $0 \%$ \\
Construction of Borehole30\% & $50 \%$ & $0 \%$ & $30 \%$ \\
Construction of Mosque10\% & $40 \%$ & $0 \%$ & $50 \%$ \\
Construction of Town Hall 20\% & $50 \%$ & $10 \%$ & $20 \%$ \\
Construction of Slop 0\% & $20 \%$ & $20 \%$ & $60 \%$ \\
\hline
\end{tabular}

Table 2 presents the various views of youths and community leaders on the self-help community development projects embarked on by the youth's in community: From the results, projects embarked on by youth's construction of drainages $40 \%$ are strongly agree $60 \%$ agree while culvert excavation 50\% strongly agree and $50 \%$ agree. With the construction of bore hole 30\% strongly agree, 50\% agree while $30 \%$ disagree. Construction of mosque $10 \%$ strongly agree, $40 \%$ agree and $50 \%$ disagree. As for construction of town hall $20 \%$ strongly agree, $50 \%$ agree while $10 \%$ strongly disagree and $20 \%$ disagree.

What are the Areas of Youth's involvements in self help Community Development Project in Sokoto North Local Government Area.

Table 3: Areas of youth's involvement

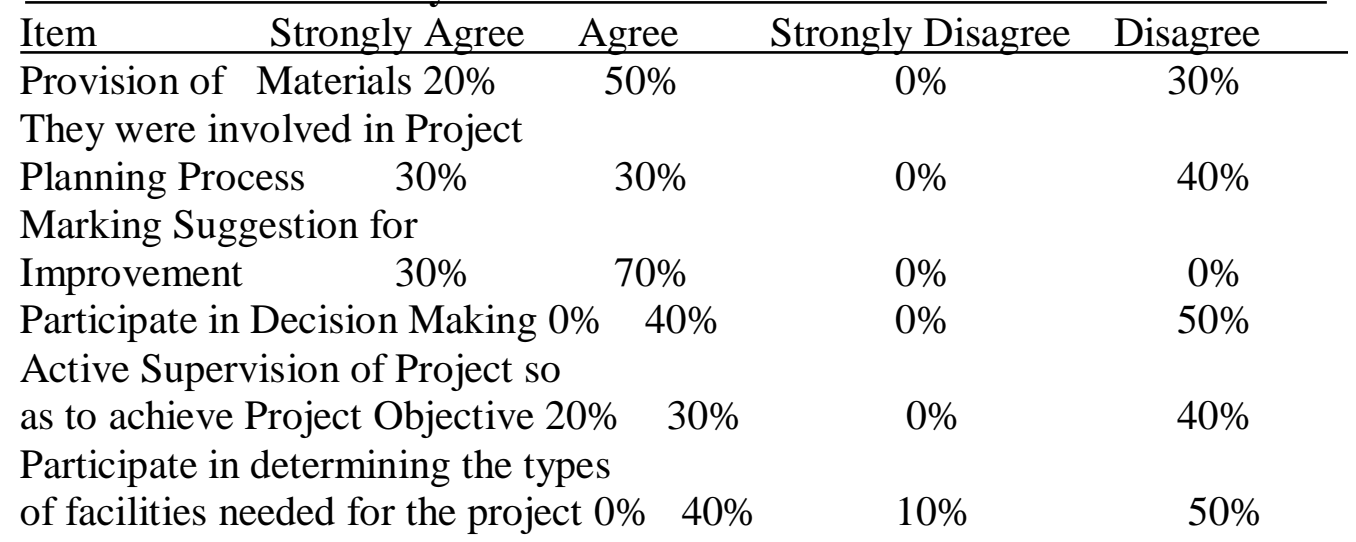


Table 3 above based on the analysis of the level of youth's involvement in provision of raw materials $20 \%$ are strongly agree while $50 \%$ Agree and $30 \%$ disagree. In the project planning process 30\% strongly Agree while 30\% Agree and $40 \%$ disagree. Also in making suggestion and improvement $30 \%$ strongly agree while $70 \%$ Agree and in decision making $40 \%$ agree while $60 \%$ disagree. As for active supervision of project so as to achieve project objective $20 \%$ strongly agree while $30 \%$ agree and $40 \%$ disagree. Perhaps in determining the types of facilities need for the project $40 \%$ Agree while $10 \%$ strongly disagree and 50\% disagree. This implying that youth's involvement in self-help community development projects was low

What are the impacts of Youth's involvement in Self- help Community Development project in Sokoto North Local Government?

Table 4: Impact of youth's involvement

\begin{tabular}{lcccc}
\hline Item & Strongly Agree & Agree & Strongly Disagree & Disagree \\
\hline Self Esteem & $10 \%$ & $80 \%$ & $10 \%$ & $0 \%$ \\
Self Employed & $10 \%$ & $50 \%$ & $10 \%$ & $30 \%$ \\
Poverty Alleviation & $20 \%$ & $70 \%$ & $10 \%$ & $0 \%$ \\
Recognition & $20 \%$ & $40 \%$ & $10 \%$ & $30 \%$ \\
\hline
\end{tabular}

Table 4 above showed that Self esteem carry 10\% strongly agree while $80 \%$ agree and $10 \%$ strongly disagree, about the Self employ $10 \%$ strongly agree, $50 \%$ agree while $10 \%$ strongly disagree and $30 \%$ disagree. More so in poverty alleviation $20 \%$ strongly agree and $70 \%$ agree while $10 \%$ strongly disagree. Mean while in recognition $20 \%$ strongly agree and $40 \%$ agree, while $10 \%$ strongly disagree, $30 \%$ disagree.

What are the constraints to youth's involvement in self- help community Development project in Sokoto North Local Government Area?

Table 5: Problems militating against youth's involvement

\begin{tabular}{lccc}
\hline Item Strongly Agree & Agree & Strongly Disagree & Disagree \\
\hline $\begin{array}{l}\text { Low Educational Background 80\% } \\
\text { Lack of Cooperation 20\% }\end{array}$ & $70 \%$ & $0 \%$ & $10 \%$ \\
$\begin{array}{l}\text { Lack of Fund from the } \\
\text { Government 70\% }\end{array}$ & $20 \%$ & $10 \%$ & $0 \%$ \\
$\begin{array}{l}\text { Financial Mismanagement 20\% } \\
\text { Parents don't allow their Children }\end{array}$ & $50 \%$ & $10 \%$ & $10 \%$ \\
$\begin{array}{l}\text { to be involved in Self-Help } \\
\begin{array}{l}\text { Community Project 10\% } \\
\text { Lack of clear ideas about }\end{array}\end{array}$ & $20 \%$ & $40 \%$ & $20 \%$ \\
the project & & & \\
\hline
\end{tabular}

Table 5 above presents the views of the respondents on the constraints to youth's involvement in self-help Community development projects. From the results both youths and community leaders agreed to all the item statements as the constraints to youth involvement, such as Low educational background $80 \%$ strongly agree while $10 \%$ agree and $10 \%$ disagree. Also like of cooperation $20 \%$ of respondents 'strongly agree and $70 \%$ agree while $10 \%$ of respondents strongly disagree. And lack of fund $70 \%$ of respondents strongly agree and $20 \%$ agree while $10 \%$ of respondents disagree. 
More over financial mismanagement 20\% strongly agree 50\% agree and $10 \%$ strongly disagree $20 \%$ disagree. Also about parents don't allow their children in community project $10 \%$ of respondents strongly agree, $20 \%$ agree and $40 \%$ strongly disagree so also $30 \%$ disagree. Respondents clearly indicate that lack of clear ideas about the project $30 \%$ strongly agree so also $30 \%$ agree and $10 \%$ strongly disagree, $30 \%$ disagree.

\section{Summary of Findings}

The summary of the major findings in the study are as follows

- At the community level, six activities were identified as a major projects embarked upon by the Youth Self-help associations in Sokoto North Local Government Area. Such as drainage excavation, by Nurawa youth community development Gidan Igwai, sanitation by Gidan Bahuri youth association and construction of culvert by Martaba youth social club waziri c. construction Mosque by Alkammawa youth movement at Magajin Rafi A. construction of Islamiyya school and slop by Taramniya youth forum Sarkin Musulmi B. And finally construction of borehole by Alkanci Youth Progressive at Magajin Rafi B.

- The areas or level of youth's involvement includes Marking Suggestion for improvement and Provision of materials among other.

- Impacts of youth's involvement have been identify as self esteem and poverty alleviation among other.

- The problems associated with community development efforts in self help community development project in the area include financial constraints, educational problems, lack of cooperation, mismanagement of projects funds and others such as lack of clear ideas about the project.

\section{Recommendations and Conclusions}

\section{Recommendations}

Many community projects have been executed in the study area with a lot of constraints such as inadequate funding, mismanagement of projects funds, educational problems and lack of co-operation among stakeholders in the provision of community projects. The following are therefore recommended to bring about accelerated sustainable development in the study area.

1. There should be education and enlightenment for youth's to participate in self help Community Development Project.

2. Youth's should be made to understand the benefits of self help Community Development Project.

3. There should be improved funding and support from government and related agencies in order to enhance activities of Youth's in Self help Community Development project.

4. Funding of projects was found to be a major constraint to community development efforts in the study area. It is therefore recommended that efforts should be made by the various communities to embark on viable money 
SER Vol. 17 (1 \& 2): December 2017

fetching community projects that can generate funds for continued functioning of their activities. 


\section{Conclusion}

Youth's have been identified as vital groups for self help community development project. They play major activities includes providing leadership and selfless services for building of Schools; drainages and culvert excavation constructions of slop among others if properly harnessed, youth's participates actively in self help community development project. However constraints to youth's involvement in self help community development project includes low educational level, lack of cooperation, inadequate fund, and lack of clear ideas about the project, among others. 


\section{References}

Afuye, H. O. (2005). Community Development in West Africa. Nigeria: Ibadan Publishing Press.

Effiong, J. B. (2012). Evidence from Yakurr L.G.A, Cross River State. International Journal of Social Science Tomorrow, 1 (6).

Hills, M. (2011). What is Community Development. Retrieved September 8, 2015, from http:www.comdeu.come/authlfan.htm.

Liveright, L. P. (2013). Who is a Youth? Canton Publishing Company, Arizona, USA.

Maxwell, G. N. (2013). Principles of Evaluation. Washington DC: National Academy Press.

Mbagwu, F. O.; Mannir A.; Ewelum J. N. \& Ezema M. C. (2016). "Youths Involvement in Self-Help Community Development Projects in Nsukka, Enugu State". European Studies, 8 (4).

Nigerian National Baseline Youth Survey (2015).

Nwosu, A. S. (1987). Self Help Projects in Rural Infrastructure Development. A Case of Fiditi Town in Oyo State Ilesanmi Publishers Ltd Ibadan

Nigerian National Bureau of Statistics Youth Survey Report (2012). Report on the High Unemployment Rate of Youths in Nigeria.

Oduaran, A. B. (1994). An Introduction to Community Development. Benin City Edo State, Nigeria: Uniben Press.

Onah, V. (2013). Contributions of Community Leaders to Community Development in Nsukka Urban (Unpublished B.Ed. Thesis). Department of Adult Education, U.N.N.

Ola, E. Aluko (2004). Social Services Planning in Nigeria in Readings in Urban and Regional Planning edited by Tunde Agbola Macmillan Nigeria Publishers Limited, Nigeria.

Saliu I. S. (2014). "Evaluation of Self Help Community Development Projects in Zungeru in Niger State, Nigeria". Greener Journal $f$ Social Sciences, ISSN: 2276-7800, 4 (3).

Tolu, L. \& Abe, O. (2011). National Development in Nigeria. Issues, Challenges and Prospects. 
Appraising the Level of Youths' Involvement in Self-Help Community Development Project in Sokoto North Local Government Area, Sokoto State

United Nations (2008). Annual Year book of Statistics.

World Bank (2010). Community based Monitoring and Evaluation Team.

World Youth Data Sheet (2010). Population Dynamics of Developing Countries.

World Youth Data Sheet (2010). Population Dynamics of Developing Countries. 